\title{
Foreign Correspondents and Bureaus
}

\section{COLLEEN MURRELL}

Swinburne University of Technology, Melbourne, Australia

The job of foreign correspondent has always been a highly desirable one that carries with it a serious news-gathering mission and a heady mixture of danger, glamour, and exoticism. A posting as a staff foreign correspondent, who lives abroad and works in an overseas bureau, is usually a reward for a journalist's achievement and experience: it means that the correspondent is trusted to carry out an organization's mission with a measure of agency and autonomy. Traditionally, for the media organization, a good spread of foreign bureaus translated into cultural capital. The prestige accrued symbolized that this was a serious news company with financial clout, and an adherence to having "our man in the thick of it" (for it usually was a man). According to John Maxwell Hamilton and Eric Jenner (2004, p. 305), having a full complement of staff correspondents reflected a belief in public service and thereby afforded media owners a right to brag. Today, overseas bureau reporting is contested, with some scholars arguing it is an anachronism to have mainly Western correspondents reporting on other countries that they cannot understand as well as local reporters would. This critical cultural perspective tends to view international news via a global dominance paradigm, working within the tradition of political economy. From this point of view, the rich Western media, and particularly the global news agencies, set the news agenda for the rest of the world's media. These macro-level perspectives follow through to meso- and micro-levels of research, which examine the kinds of coverage that are undertaken, and argue that non-Western cultures are portrayed through a distorting cultural lens, reflecting Western interests rather than local interests, and de-emphasizing local agency. For others, working in the tradition of news production research, bureau correspondents still represent the gold standard of reporting, as this luxury of time and resources allows a reporter to work continuously alongside local producers and fixers, which opens a window onto local perspectives. Today, the challenge of free digital news sites, cheap technology, globalization, and the growth of citizen journalism have all added to the questioning of the traditional foreign correspondent model. On top of this, despite spikes of interest in foreign news (due to specific events such as the 9/11 terror attacks or the 2003 war in Iraq), U.S. media organizations, in particular, argue there is less interest in foreign news than there is in domestic news. In 2018 a high profile, freelance foreign correspondent, Sulome Anderson, appeared in an article titled, Freelancing abroad in a world obsessed with Trump (Schwartz, 2018). She said she was returning to the United States from Beirut because editors were not commissioning pieces from her as they were obsessed with the president. The media's interest in President Trump is underscored by a Shorenstein Center report (Patterson, 2017), which states that Trump was the focus of $41 \%$ of U.S. news coverage in his first 100 days as president-three times the amount of coverage of previous holders of the office.

The International Encyclopedia of Journalism Studies. Tim P. Vos and Folker Hanusch (General Editors), Dimitra Dimitrakopoulou, Margaretha Geertsema-Sligh and Annika Sehl (Associate Editors). (c) 2019 John Wiley \& Sons, Inc. Published 2019 by John Wiley \& Sons, Inc. 
When Richard Sambrook (2010) posed the question: "Are foreign correspondents redundant?" the scholar and former head of BBC News was pondering if it was the end of an era for expensive foreign bureaus. He forecast correctly that cash-strapped news organizations would elect to spend their dwindling dollars on responsive news-gathering budgets rather than on infrastructure for keeping a foreign correspondent abroad, with its attendant costs of additional staff, office and house rentals, plus health care and education for their families. In days of plenty the staff often extended to drivers, producers, fixers, camera operators, and editors. These financial costs have now to be weighed against the alternatives, which are news agency subscriptions, and free access to instant video and citizen journalists via mobile phones and platforms such as Twitter, Facebook, and Instagram. Ever improving technology has also aided the growth of "parachute journalism," in which reporters are flown into a crisis location from the company's headquarters or from regional hub bureaus. From there they mop up global stories, often after they have broken. A number of media scholars have tackled the advantages and disadvantages of this mode of delivery, declaring it to be highly derivative (Rosenblum, 1979); superficial and subject to propaganda (Pedelty, 1995); and useful and inevitable (Erickson \& Hamilton, 2006). In an article called "Redefining Foreign Correspondence," Hamilton and Jenner (2004, p. 313) explored a variety of new types of journalists who were emerging on the back of a globalized workforce-these included: the "foreign foreign correspondent" (a foreign national for hire), the "local foreign correspondent" (a local reporter who travels abroad temporarily to cover an aspect of their domestic story), the "foreign local correspondent" (a journalist working for a news outlet whose material you can now read online), the "in-house foreign correspondent" (an overseas employee who reports back internally to their own organization), the "premium service foreign correspondent" (a specialist foreign reporter), and the "amateur correspondent" (a person who witnesses a news event). While these approaches to hiring more local reporters can be an easy and cheaper option for English-speaking media, they are not always an option for Finnish- or Dutch-speaking media. The transnational broadcaster, $\mathrm{CNN}$, takes issue with the whole notion of "foreign." Ulf Hannerz (2000, p. 85) wrote that CNN's founder, Ted Turner, had threatened to sack any employee who used the word foreign as in foreign correspondent. He said, "Nobody among the viewers of CNN should ever be made to feel that he or she lived in a foreign country." To this end, CNN has international correspondents. Although most media today experiment with a mixture of parachute and local journalists, even proponents of this type of reporting suggest it is not as ideal as having bureau-based correspondents. According to Erickson and Hamilton (in Perlmutter \& Hamilton, 2007, p. 145), while parachute journalists might solve the problem of financial constraints, bureau-based correspondents were still vital for strong news coverage.

The business of foreign correspondence has a long history. According to Anthony Smith (1979, p. 18) a "formal network of correspondents and intelligence agents" had been in place across the European continent since the late Middle Ages. These people fed back news in the form of corantos to a country's elite, long before the birth of newspapers. The first official "war correspondents" were dispatched during the Crimean War of 1853-1856 and the sensational news that they published ensured that thereafter the most important aspects of foreign correspondence were eyewitness news and having 
your "boots on the ground." BBC foreign correspondent Allan Little made the case for eyewitness journalism to Sambrook (2010, p. 102) when he said that it was "the most decent" form of reporting, and that it had the power to "settle part of the argument" and counter propaganda. Living permanently abroad, means a correspondent is both an insider and an outsider at the same time. In British, American, and Australian media, the usual term of a posting is a maximum of three years, after which managers deem reporters to be in danger of becoming too much of an insider, and they will be recalled or sent on to other overseas postings. The plum postings are London, Washington, or high news locations like Jerusalem. Mark Pedelty (1995) was the first to examine the work of foreign correspondents in a forensic manner, while being embedded with them in San Salvador during the country's civil war. He found that as a group they had variegated amounts of what French sociologist Pierre Bourdieu called embedded, objectified, and institutionalized cultural capital. The career path they had chosen was not the management ladder, but a ladder that led towards greater autonomy. Those with the most cultural capital worked as staff correspondents for prestigious outlets such as The New York Times. The reporters with the least cultural capital worked as stringers, freelancers, or were local reporters for less well-known media. Generally speaking, the reporters with the most numerous bureau postings tend to be ones working for news agencies. These postings enhance their capital, but they tend to remain fairly anonymous to the public.

In the United States at the height of the boom in international news coverage in the 1980s and 1990s, even the regional and metropolitan newspapers had bureaus abroad-for example, The Chicago Tribune had offices in cities including Mexico City, Moscow, Baghdad, and Buenos Aires (Enda, 2011). Between 1998 and 2011, 18 of these newspapers and two newspaper chains shut every last foreign bureau (Kumar, 2011). Today the "big four" legacy newspapers retain a number of bureaus, but these too have been reduced or have had personnel cut. In 2018, inquiries made to these organizations by this author, found that, The New York Times has 27 correspondents based in 25 bureaus; The Washington Post has 24 correspondents in 16 overseas bureaus; The Los Angeles Times has 6 foreign correspondents based in 5 bureaus, and the Wall Street Journal has 12 bureaus (Murrell, unpublished data). Some of the people counted as working in these offices may be full-time correspondents but others are stringers, or people on contract. These days, media companies do not necessarily rent offices for them, but count their employees' apartments as being their offices. Most major media outlets still subscribe to news agencies, which offer a more cost-efficient way of sourcing foreign news; AP has 79 overseas bureaus and Bloomberg has 100. In broadcast, there has also been shrinkage of both bureaus and reporters. In 2018, NBC has an international operation based in London, four other bureaus with correspondents, producers in five countries, and a stake in Euronews, headquartered in France; CNN has 47 bureaus; CBS has 11 bureaus; and ABC News has four foreign correspondents (three in the United Kingdom and one in Asia).

In the United Kingdom there has been a similar flight from expensive bureaus, with many traditional newspapers keeping only a handful of full-time staff abroad or teaming up with other organizations to strengthen news-gathering partnerships. The BBC, for a number of years, has pursued a stratified approach to its staff sent abroad, with reporters for the national news services usually being better paid and resourced than 
staff working for the BBC World Service. Between 2011 and 2014 the organization carried out a news-gathering audit of its foreign bureaus, resulting in a widening of overseas positions available, from "local reporter" to "foreign reporter" to "foreign correspondent," with each having a different salary structure and employment conditions. The BBC still rotates senior correspondents through well-staffed bureaus in places like Washington, Beijing, and Jerusalem, but it also employs many more local journalists to report from their own countries. A gender pay controversy at the corporation in 2017 led to the discovery that men and women were often paid different salaries for similar jobs. One outcome was that the China Correspondent, Carrie Gracie, stood down from her role as Beijing Bureau Chief when she discovered that Jon Sopel, the Washington Bureau Chief, was being paid a great deal more than her. Currently discussion continues in the media as to whether this particular discrepancy was based on gender, or the fact that Gracie had come up through the BBC World Service newsroom, or whether or not the Washington bureau was considered to be more important than the Beijing bureau. Overall, the BBC reports that its "news teams" operate out of 125 cities in 70 countries.

One country that has been investing heavily in foreign correspondents and overseas bureaus in recent years is China. According to Iginio Gagliardone and Nyiri Pál (2017, p. 1050), Chinese media are putting in place an impressive network of foreign bureaus, thereby strengthening soft diplomacy ties with multiple countries and reinforcing the China brand. Xinhua News Agency, China Central Television (CCTV), China Radio International (CRI), People's Daily and China Daily were reported to have received between $\$ 2$ to $\$ 9$ billion to create foreign networks, some of which has been spent expanding into Africa (Gagliardone \& Pál, 2017, p. 1050). In 2017, Xinhua had 27 bureaus in sub-Saharan Africa, more than any other news agency (Gagliardone \& Pál, 2017, p. 1053). Long recognizing China's importance as a powerful player in the Asia-Pacific region, the Australian ABC has had a Beijing bureau since 1973. Across the decades the $\mathrm{ABC}$ has shown a repeated tendency to open and close bureaus in swift reaction to world events, with a dozen or so bureaus spread thinly across the globe while retaining a constant presence in the United States and United Kingdom. In 2015, the ABC announced that it would close a number of its bureaus, while creating "hub bureaus" in Washington, London, Beijing, and Jakarta (Murrell, 2016, p. 246). This involved rebadging some posts from being bureau-based correspondents to apartment-based video-journalists (VJs), with all savings redirected to an assignments budget for travelling reporters and to building up a global network of freelancers. The $\mathrm{ABC}$ has also experimented with short-term, pop-up bureaus to cover places like Kabul, where conflict might be covered for a while but there is no long-term commitment. Correspondent Sally Sara described her bureau in Kabul in 2011 as more of a bedroom than a bureau as it measured only 12 paces long and eight paces wide. In similar ways cash-strapped CBC-Radio Canada has also elected to retain bureaus in London, Washington, and New York, while changing to VJ positions in Beijing and Jerusalem. Like the $\mathrm{ABC}$, it has experimented with pop-up bureaus and continues to rely on a stable of freelancers for breaking stories, and Skype for increased use of "live hits" (Murrell, 2016, p. 248). These days, the reporters sign off their stories from their hub bureau locations but they may be nowhere near the action being covered (Murrell, 2016, p. 252). 
The shuttering of permanent foreign bureaus is to be regretted. These bureaus do offer a long-term perspective on the politics, economics, and social issues of certain carefully selected cities, which usually reflect intrinsic geopolitical importance (Washington, Beijing, London, Brussels), historical ties or trade, or a location of conflict (Baghdad, Jerusalem). While scholars gathered under the umbrella of the "global dominance paradigm" argue that these old structures further cement the views of Western dominance, the bureau system is hard to surpass in terms of commitment to stories over time. For example, the BBC, $\mathrm{CNN}$, and a handful of other media organizations stayed the course in their reinforced Baghdad bureaus for a lengthy period following the 2003 Iraq War, despite the dangers. The reporters who remained, argued that it was vital to bear eyewitness to the worsening situation, even if they had to rely on local fixers and producers more than was usual (Murrell, 2010). When covering Syria became too dangerous for all foreign journalists, media companies and news agencies alike resorted to selecting videos from YouTube to cover the conflict (Murrell, 2017). Nobody would argue that this is an ideal way to conduct foreign news gathering, particularly the news agencies. Many news outlets (such as Channel 4 News in the United Kingdom) worked hard to find brave local people who could share their experiences in words or videos from behind the front line. But once towns in Syria were freed from ISIS rule, media companies sent back their Middle East-based correspondents (and parachuting reporters) to offer analysis and conduct investigations from the scene.

A well-resourced and agile media company is one that offers a portfolio of international news coverage that weaves together material from the Internet and citizen journalists, with news agency material and on-the-ground reporting from its own journalists and analysts. As fake news sweeps the globe, and news bots churn out lies and disinformation, trusted correspondents in situ are needed to verify the wild claims upon our attention. Media research in the future needs to concentrate on the evolution that is currently underway in international news gathering, charting the content that correspondents cover and how it is carried out in news production terms. We cannot know what is worth financing or saving, unless further analysis is undertaken to discover the value of what is currently being done.

SEE ALSO: North American Journalism; Global News Organizations; Parachute Journalism; Transnational Journalism; Public Service Broadcasting; Journalists; Wire Service Journalism; Freelance Journalists and Stringers; News-Gathering Technologies; Eyewitnesses;

\section{References}

Enda, J. (2011, Dec/Jan). Retreating from the world. American Journalism Review. Retrieved from http://ajrarchive.org/article.asp?id=4985

Erickson, E., \& Hamilton, J. M. (2006). Foreign reporting enhanced by parachute journalism. Newspaper Research Journal, 27(1), 33-47.

Gagliardone, I., \& Pál, N. (2017). Freer but not free enough? Chinese journalists finding their feet in Africa. Journalism, 18(8), 1049-1063. doi:10.1177/1464884916636171 
Hannerz, U. (2000). Foreign news: Exploring the world of foreign correspondents. Chicago, IL: University of Chicago Press.

Hamilton, J. M., \& Jenner, E. (2004). Redefining foreign correspondence. Journalism, 5(3).

Kumar, P. (2011, Dec/Jan). Foreign correspondents: Who covers what. American Journalism Review. [Online]

Murrell, C. (2010). Baghdad bureaux: An exploration of the interconnected world of fixers and correspondents at the BBC and CNN. Media, War \& Conflict, 3(2), 125-137.

Murrell, C. (2016). The international newsgathering challenge for public service Australian and Canadian 24/7 TV channels. In S. Cushion \& R. Sambrook (Eds.), The future of 24-hour news: New directions, new challenges. New York, NY: Peter Lang.

Murrell, C. (2017). The global television news agencies and their handling of UGC video from Syria, media, war and conflict. First published April 28, 2017. doi:10.1177/1750635217704224

Patterson, E. (2017, May 18). News coverage of Donald Trump's first 100 days. Shorenstein Center Report. Retrieved from https://shorensteincenter.org/news-coverage-donald-trumpsfirst-100-days/

Pedelty, M. (1995). War stories: The culture of foreign correspondents. New York, NY: Routledge. Perlmutter, D., \& Hamilton, J. M. (Eds.). (2007). From pigeons to news portals: Foreign reporting and the challenge of new technology. Baton Rouge, LA: Louisiana State University Press.

Rosenblum, M. (1979). Coups and earthquakes: Reporting the world to America. New York, NY: Harper \& Row.

Sambrook, R. (2010). Are foreign correspondents redundant? The changing face of international news. Oxford, UK: Reuters Institute for the Study of Journalism.

Schwartz, Y. (2018, January 30). Freelancing abroad in a world obsessed with Trump. Columbia Journalism Review. Retrieved from https://www.cjr.org/covering_trump/trumpimpact-foreign-reporting.php

Smith, A. (1979). The newspaper: An international history. London, UK: Thames \& Hudson.

\section{Further reading}

Murrell, C. (2015). Foreign correspondents and international newsgathering: The role of fixers. New York, NY: Routledge Research in Journalism Series.

Patterson, E. (2011, Dec/Jan). Retreating from the world. American Journalism Review. Retrieved from http://ajrarchive.org/article.asp?id=4985

Poushter, J. (2017, May 16). Many people in other countries closely follow news about the US. Pew Research Center. Retrieved from http://www.pewresearch.org/fact-tank/2018/01/16/manypeople-in-other-countries-closely-follow-news-about-the-u-s/

Williams, K. (2011). International journalism: Key texts. Los Angeles, CA: SAGE.

Colleen Murrell is an associate professor and course director of journalism at Swinburne University of Technology in Melbourne. She conducts research into international news gathering and social media and wrote Foreign Correspondents and International Newsgathering: The Role of Fixers. She is a co-secretary of the Journalism Education and Research Association of Australia (JERAA) and teaches broadcast journalism and international reporting. Previously she worked as a producer, reporter, and news editor for international media organizations including the BBC, ITN, CBC, AP, and ABC Australia. In these jobs she travelled widely in the Middle East, Europe, and North America. 
Please note that the abstract and keywords will not be included in the printed book, but are required for the online presentation of this book which will be published on Wiley's own online publishing platform.

If the abstract and keywords are not present below, please take this opportunity to add them now.

The abstract should be a short paragraph up to 200 words in length and keywords between 5 to 10 words.

\begin{abstract}
The markers of a media organization's prestige have traditionally been the number of foreign correspondents and overseas bureaus it retains. Until recently, flagship media companies would pay handsomely to locate bureaus in financial or political capitals, alongside places experiencing ongoing conflict. But the cultural capital thus accrued is expensive, and increasingly money and resources are being shifted from fixed infrastructure costs to news-gathering budgets which finance parachuting reporters to cover breaking news stories. Today the world's major media organizations are positioning their few "hub bureaus" in strategically selected major cities, from where foreign correspondents can report in situ on their particular country or on behalf of nearby countries or wider regions. These high profile correspondents form part of a media organization's international news-gathering portfolio, which may include news agency subscription, travelling reporters, freelancers, stringers, and local journalists.
\end{abstract}

\title{
KEYWORDS
}

fixers; foreign bureaus; foreign correspondents; global news agencies; international news gathering; local producers; news production; parachute reporting; transnational journalism 